by Chikondi Chisenga ${ }^{1,2 *}$, Yan Jianguo ${ }^{I}$, Islam Fadel ${ }^{3}$, Mark van der Meijde ${ }^{3}$, and Estella A.

Atekwana ${ }^{4}$

\title{
Updated tectonic terrane boundaries of Botswana determined from gravity and aeromagnetic data
}

\author{
${ }^{1}$ State Key Laboratory of Information Engineering in Surveying, Mapping and Remote Sensing (LIESMARS), Wuhan University, Box 129, \\ Luoyu Road, Wuhan, China; *Corresponding author, E-mail: cchisenga@must.ac.mw \\ ${ }^{2}$ Department of Earth Sciences, Ndata School of Climate and Earth Sciences, Malawi University of Science and Technology, P.O. Box 5196, \\ Limbe, Malawi \\ ${ }^{3}$ University of Twente, Faculty for Geo-information Science and Earth Observation (ITC), P.O. Box 217, 7500 AE Enschede, The Netherlands \\ ${ }^{4}$ Department of Earth Sciences, College of Earth, Ocean, and Environment, University of Delaware, Newark, Delaware, USA
}

(Received: July 20, 2019; Revised accepted: March 26, 2020)

https://doi.org/10.18814/epiiugs/2020/020054

We used existing high-resolution gravity and aeromagnetic data to map the crustal units underneath Botswana. The thick sedimentary cover in this region has always been a challenge to understand the geological and tectonic configuration of unexposed crustal terranes using traditional geological methods. We utilized a standard physical mapping technique to convert previously obtained gravity and aeromagnetic data into apparent density and magnetic susceptibility maps, respectively, of the crustal tectonic terranes. Then, the derived maps were fused into a single apparent physical map to facilitate its geotectonic interpretation. The results showed that most of the tectonic boundaries were inaccurately mapped due to limited availability of high-resolution geophysical information. Moreover, we found that some terranes were missing from the current tectonic map. We used the apparent physical property map and the basement rocks information from literature to significantly update the tectonic map of Botswana, which shows the spatial extent of the geological units beneath the Kalahari sedimentary cover. The new map gives an insight into the geodynamics of Botswana crust.

\section{Introduction}

The southern African tectonic region represents a complex geological history that has been shaped by rifting, amalgamation, and intrusive magmatic events (Hartnady et al., 1985; Kröner, 1985). Botswana is crucially located within this region where the different tectonic terranes meet. Furthermore, the region is endowed with the presence of numerous mineral deposits, which includes but not limited to greenstone belts deposits, copper, gold, and diamonds associated with specific tectonic terranes (Evans et al., 2016; Frost-killian et al., 2016; Kinnaird et al., 2016; Pedley et al., 2016; Smith and Beukes, 2016; Tucker et al., 2016; Viljoen, 2016). For instance, diamonds and base metals are located in the ancient cratonic regions in Botswana, South Africa and Zimbabwe, that requires accurate tectonic terrane identification, mapping and delineation to better investigate this mineral wealth. However, the tectonic terranes in Botswana have undergone multiple episodes of deformation (Begg et al., 2009) including rifting in the Ghanzi-Chobe Zone that resulted in the formation of the Okavango Rift Zone and the Kgwebe volcanism (Modie, 1996), Kibaran Orogeny (Thomas et al., 1993), metamorphism (Aldiss, 1991; Roering et al., 1992; Coward and Fairhead, 2002), the Damara Orogeny (Gray et al., 2008), magmatic intrusions that formed mafic complexes (Hutchins and Reeves, 1980; Aldiss and Carney, 1992) and large scale subsidence that formed the Nosop and the Passarge sedimentary basins (Haddon, 2005). The subsurface processes have rendered the boundaries and internal architecture of the crustal tectonic terranes underneath Botswana not to be well understood (Singletary et al., 2003). This is also partly due to the Carboniferous and Jurassic Karroo sediments and the thick Kalahari sands of Phanerozoic (Cenozoic) origin that concealed $\sim 80 \%$ of Botswana's basement structure (Key and Ayres, 2000). As a result, traditional geological mapping methods provide limited information on the geological and tectonic configuration of these unexposed crustal terranes underneath the Kalahari sedimentary cover.

Geophysical methods have been traditionally used for regional reconnaissance, imaging and modeling of crustal blocks. They can provide a rapid, high-resolution, and homogeneous data coverage that enables a detailed and accurate mapping of subsurface structures (Hutchins and Reeves, 1980; Reeves and Hutchins, 1982; Yawsangratt, 2002; Walker et al., 2010; Chisenga, 2015; Ramotoroko et al., 2016; Fadel et al., 2018; Fadel et al., 2020). Better delineation of the terrane boundaries by geophysical methods could help to understand the lithospheric structure that can lead to better mineral exploration programs. In southern Africa for example, geophysical techniques have helped to more accurately define the boundaries for the Congo Craton, Kalahari Craton, Bangwelu Blocks and the discovery of the Niassa Craton east of the Luangwa rift that enables further understanding of the geodynamic evolution of the Archaean crust in this area (Ranganai et al., 2002; Khoza et al., 2013; Sarafian et al., 2018; Emry et al., 2019). In Botswana in particular, geophysical techniques helped to image the 
extensions of Archean granite-greenstone terrane from South Africa into southern Botswana, the possible existence of a macro-craton beneath the Nosop Basin, and the extension of the Congo Craton into northern Botswana (Khoza et al., 2013; Ramotoroko et al., 2016; Fadel et al., 2018).

Here, we utilize high-resolution gravity and aeromagnetic data to update the tectonic terrane boundaries of Botswana. We used a standard physical mapping approach to derive the regional apparent density and magnetic susceptibility maps of Botswana from the gravity and aeromagnetic data, respectively. Then, the derived maps were fused into a single apparent physical properties map to highlight the different tectonic terranes in the area. The derived apparent physical properties map was used to define the extent and configuration of tectonic terranes and the relations between Archean and Proterozoic crustal components in Botswana, by identifying tectonic terranes boundaries as they appear in the map. Finally, we produced an interpreted Precambrian basement tectonic map of Botswana that satisfies both the geophysical properties and geological information from previous studies.

\section{Tectonic Setting of Botswana}

The tectonic terranes in Botswana have a complex history that reflects a series of rifting, amalgamation, and intrusive magmatic events. Botswana is located between two cratonic terranes: the Congo Craton in the northwest and the Kalahari Craton in the southeast (Fig. 1a). The term Kalahari Craton refers to the Archean block within the southern African tectonic region that comprise of the Zimbabwe Craton, the Kaapvaal Craton and the Limpopo Belt (Begg et al., 2009). The cratonic blocks are surrounded by relatively younger orogenic belts and sedimentary basins of Proterozoic age (Kröner, 1985; Begg et al., 2009; Fig. 1a). The amalgamation of these crustal terranes forms the Precambrian basement tectonic map of Botswana (Fig. 1b). In the following subsections, we will describe the tectonic terranes and their deformation history in chronological order.

\section{Archean Blocks}

The summary of the Archean crust in Botswana is adapted from Begg et al. (2009). The Archean units in Botswana include the Zimbabwe Craton (3.5-2.57 Ga), the Kaapvaal Craton (3.7-3.2 Ga), the Congo Craton, and the Limpopo-Shashe Belt (2.7-2.6 Ga, Fig. 1; Hartnady et al., 1985). The Congo Craton and the São Franciso Craton in South America, not shown on the map, are widely accepted to have amalgamated together as a single cratonic block around 2.05 Ga until the break-up of Africa and South America around $140 \mathrm{Ma}$ (Schannor et al., 2019). The Congo Craton is separated from the broader Zimbabwe/Kaapvaal Cratons by the Neoproterozoic Damara and Ghanzi-Chobe Belts (Haddon, 2005). The Damara Belt is subdivided into four units, namely, the Roibok Complex, the Kwando Complex, the Koanaka Group the and Chihabadun Complex (Fig. 1b; Key and Ayres, 2000). The southeastern boundary of the Congo Craton is still poorly defined, despite recent studies placing it in northwestern Botswana (Singletary et al., 2003; Khoza et al., 2013). The Kaapvaal Craton consists of granitoids with gneisses and narrow greenstone belts (Eglington and Armstrong, 2004).
The Archean craton is mostly covered by the Kalahari sands with exposures in the eastern part of Botswana. The craton was intruded by the Molopo Farm's ultramafic rocks and the Tsetseng Complex among others (Hutchins and Reeves, 1980; Reeves and Hutchins, 1982; Key and Ayres, 2000). The Zimbabwe Craton consists of folded volcano-sedimentary sequences of greenstone belts, which are associated with granites and gneisses. The craton was amalgamated to the Limpopo Belt and the Kaapvaal Craton by east-directed movement (Begg et al., 2009).

The Limpopo-Shashe Belt between the Zimbabwe and the Kaapvaal Cratons is a Neo-Archean crust that was reworked in the Proterozoic era (Schaller et al., 1999; Khoza et al., 2013). The Neo-Archean Limpopo-Shashe Belt is divided into the Northern Marginal Zone (NMZ), the Central Zone (CZ), and the Southern Marginal Zone (SMZ; McCourt et al., 1995; Ranganai et al., 2002; Fig. 1b). The belt is highly deformed with different complex tectono-thermal history and several high-grade metamorphic events. Lithologically, the Archean crustal blocks in Botswana are similar, but they differ by the thermo-tectonic regimes that affected their metamorphism (Schaller, 1999).

\section{Proterozoic Blocks}

The Proterozoic geology in Botswana consists of mobiles belts and major mafic intrusions (Key and Ayres, 2000; Singletary et al., 2003). Furthermore, the Passarge and the Nosop deep sedimentary basins, which are filled with sediments belonging to the Ghanzi-Chobe Group, were formed in the Neoproterozoic era (Haddon, 2005).

The Magondi Belt includes thick sedimentary sequences and volcanic rocks, which were later deformed and metamorphosed (Treloar, 1988; Majaule et al., 2001; Master et al., 2010). Tracing the Magondi belt in Botswana was based on the northeast-trending magnetic structures from the Zimbabwe side, around the Zimbabwe Craton, which joined the Limpopo-Shashe Belt in Botswana (Key and Ayres, 2000). The drillcore geology of high-grade paragneisses at Gweta in Botswana also correlates well with the Magondi Belt lithology at Dett in Zimbabwe (Carney and Dowsett, 1991). The western and northern edges of the Kaapvaal Craton contain the high magnetic Mesoproterozoic basicultrabasic Kheis Belt, the Tshane Complex, the Xade Complex, and the Okwa Block, which are overlain by the Kalahari sedimentary cover (Key and Ayres, 2000). The Kheis Belt consists of basalts and clastic sediments located between the Kaapvaal Craton to the east and the Nosop Basin to the west. The Kheis Belt and the Tshane Complex form a distinct high magnetic feature that extends northwards to the Okwa Block (Hutchins and Reeves, 1980). The Okwa Block includes mafic and felsic magmatic complexes (Aldiss and Carney, 1992; Mapeo et al., 2006). The central part of Botswana contains the Xade Complex, which is a magnetic mafic intrusion, sitting next to a small and highly magnetic circular feature termed the Tsetseng Complex.

The Ghanzi-Chobe Zone contains volcano-sedimentary sequences of rocks that overlay the highly magnetic Kgwebe formation and the north-western Botswana rift (Modie, 1996, 2000; Kampunzu, 2000). In this paper, we defined the north western group as the Proterozoic tectonic terranes located in the northwest of the Ghanzi-Chobe Zone. The area is believed to be the southern end of the Congo Craton that lies underneath the exposed Proterozoic rocks (Khoza et al., 2013). Geological terranes in this region are the Kwando Complex, the Quang- 


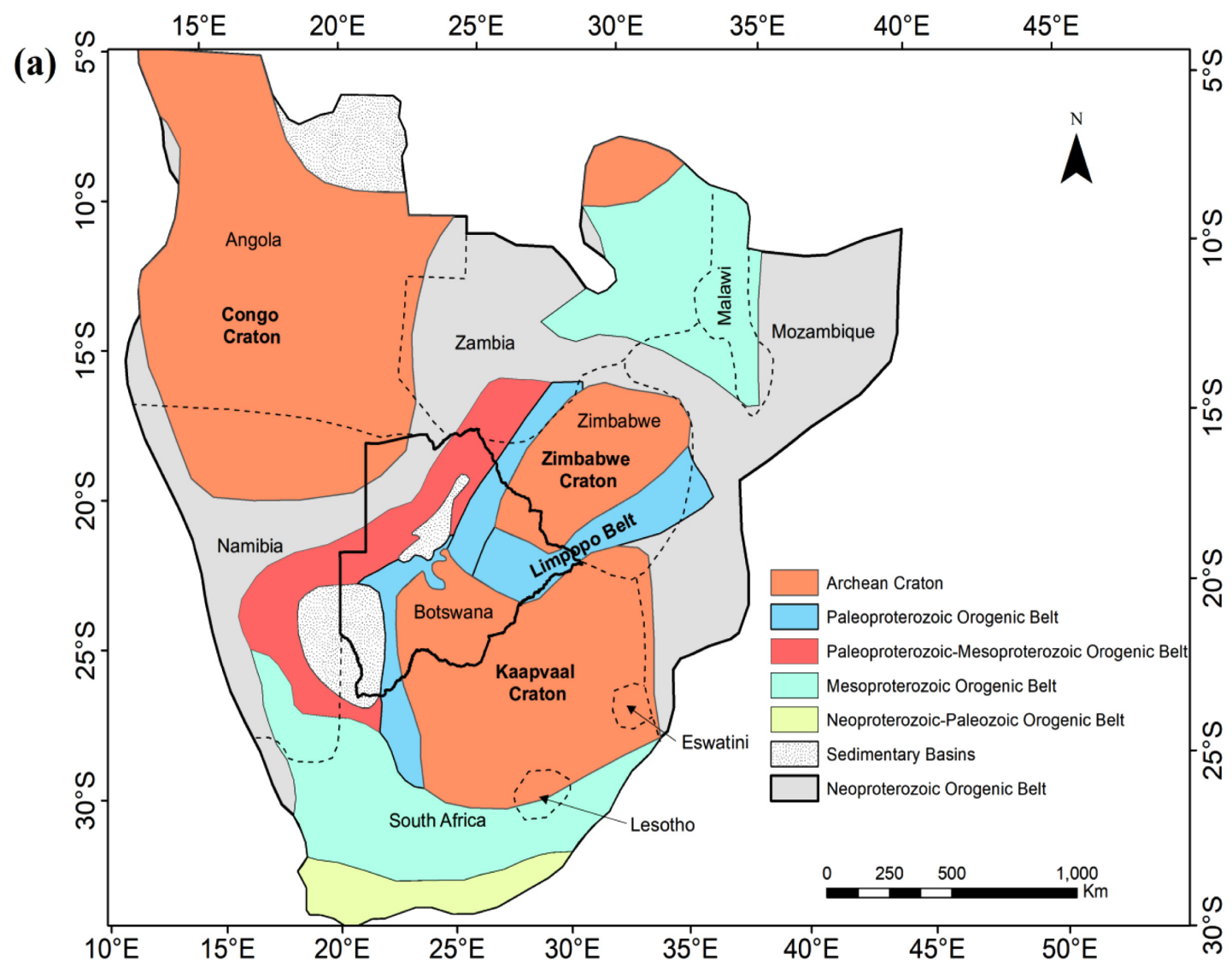

(b)

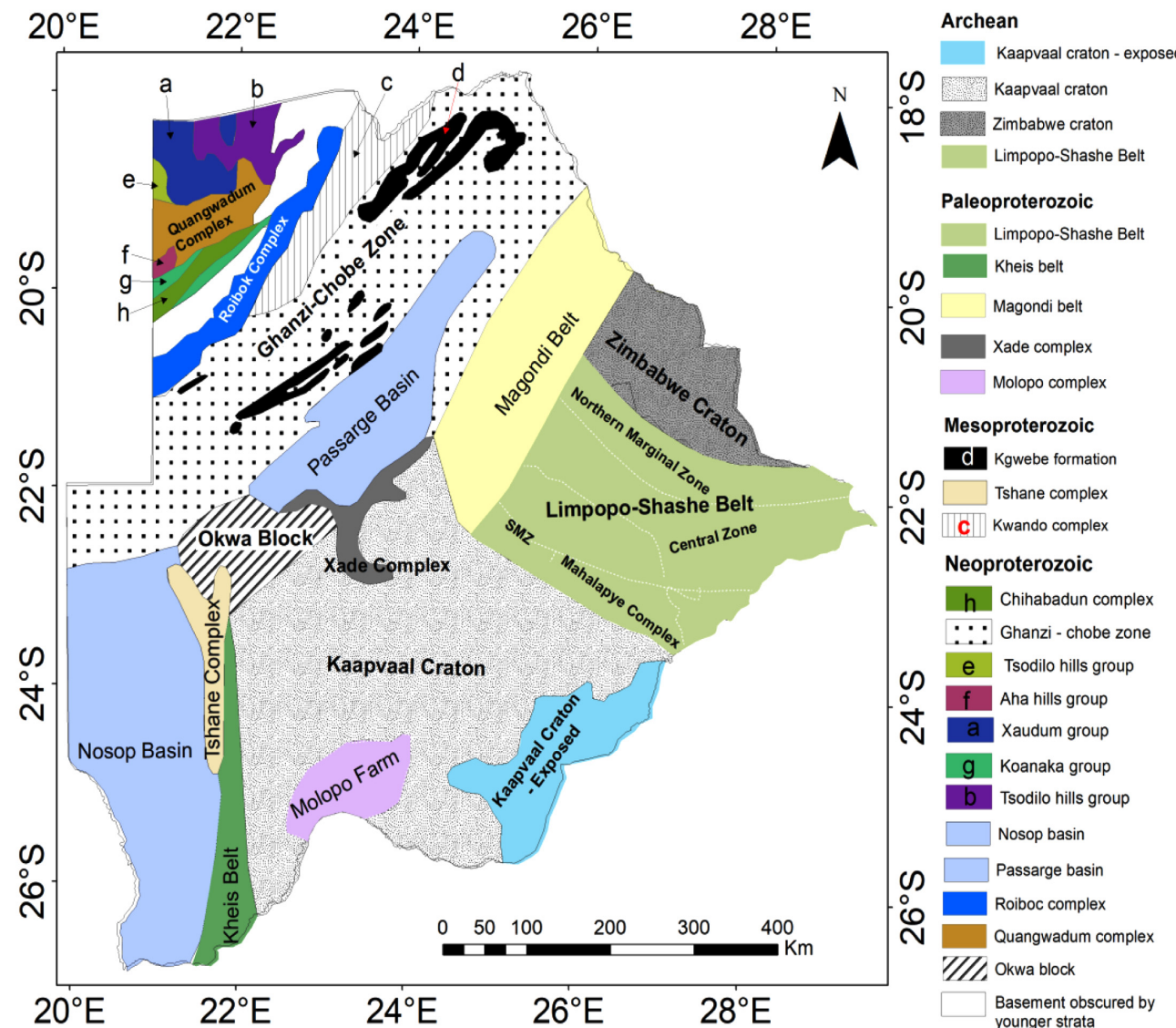

Figure 1. (a) The southern Africa tectonic configuration; and (b) The modified subsurface Precambrian basement tectonic map of Botswana after Key and Ayres (2000), Ranganai et al. (2002), and Singletary et al. (2003). 
wadum Complex, the Xaudum Complex, the Tsodilo Hills Complex, the Roibok Complex, the Aha Hills Group, and the Koanaka Group (Fig. 1b; Key and Ayres, 2000). The Roibok Complex, the Koanaka Group, and the Kwando Complex are northeasterly pronounced striking outcrops obscured by Kalahari sedimentary cover. These terranes were mostly mapped using geophysical data (Hutchins and Reeves, 1980; Reeves and Hutchins, 1982), drilled borehole (Singletary et al., 2003) and geological mapping of exposed outcrops (Aldiss and Carney, 1992; Carney et al., 1994; Key and Ayres, 2000; Modie, 2000).

\section{Methodology}

\section{Dataset}

This study used existing gravity and aeromagnetic data of Botswana, obtained from the Botswana Geosciences Institute (BGI). The data were provided as a $1 \mathrm{~km}$ Bouguer anomaly grid (Fig. 2a) and a $50 \mathrm{~m}$ TMI grid (Fig. 2b). Previous studies have used the same data to obtain the Moho depth (Leseane et al. 2015; Chisenga, 2015) and to determine the terrane configurations for selected parts of Botswana (Hutchins and Reeves, 1980; Reeves and Hutchins, 1982; Yawsangratt, 2002; Corner et al., 2012; Chisenga, 2015). Furthermore, the data was vital in determining the extent of the greenstone belt from South Africa into southern Botswana as an indicator for hidden mineral potential (Ramotoroko et al., 2016). It was also utilized in the determination of the Curie point depth and the extent of incipient rifting in northern Botswana (Leseane et al., 2015), and the improvement in the understanding of the geological evolution of some tectonic regions in Botswana (Ranganai et al., 2002; Walker et al., 2010). Despite that the data had previously been extensively used, our study obtains new and unique geological terrane configurations beneath the thick Kalahari sand in Botswana by integrating the information from this old gravity and aeromagnetic data

(a)

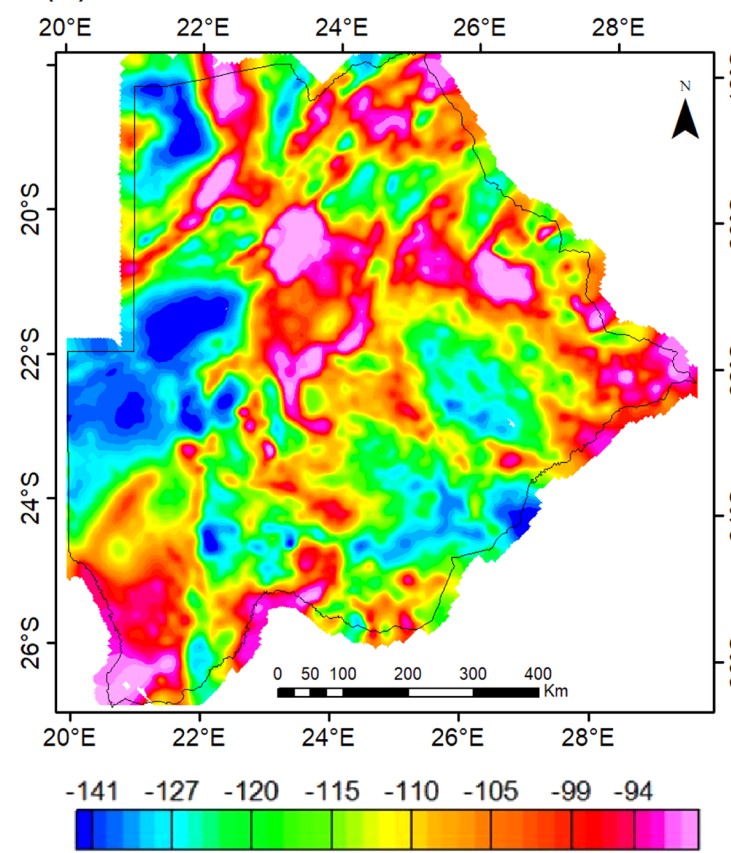

with previously obtained geophysical and geological information.

The gravity data have a spatial resolution of $\sim 7.5 \mathrm{~km}$ and is based on the compilation of data acquired in two national-wide gravity surveys from 1972-1973 and 1998-1999, with additional data provided by different companies. The first national gravity survey started in 1972, with funding from the British oversees development ministry (Hutchins and Reeves, 1980). The survey was conducted in two phases; the first phase was acquired by aircraft with a gravity accuracy of $+/-0.05 \mathrm{mGal}$ and a total of 23 gravitational base stations. The second phase involved the establishment of 1854 gravity stations, tying of 277 gravity stations from northern Botswana survey with an accuracy of $+/-0.03 \mathrm{mGal}$. The survey involved ground sampling with a sample distance of $10 \mathrm{~km}$. Furthermore, 300 stations in inaccessible areas were acquired by a helicopter (Hutchins and Reeves, 1980). The second survey had an average density of 37 gravity stations per $100 \mathrm{~km}^{2}$ (Yawsangratt, 2002). It filled the gaps that were not covered by the first survey of 1972-1973.

The aeromagnetic data is a compilation of different surveys and dataset from different companies acquired since the 1960s. The first aeromagnetic survey started in October 1975, with a total of 150,000 $\mathrm{km}$ lines survey flown and interpreted in 1977 (Reeves and Hutchins, 1982). To fill in the gaps of the first survey, a new survey was carried out in 1977 and 1987 that covered the entire Botswana. The data was compiled into one dataset in early 1990s and then added to the data acquired by the new survey of 1996 .

\section{Apparent Density}

Apparent density mapping transforms Bouguer gravity anomalies into density distribution, with an assumption that the rock densities vary laterally and not vertically to a certain depth (Gupta and Grant, 1985). We separated the long-wavelength signal that are approximately associated with mantle sources using a $1000 \mathrm{~km}$ Butterworth high pass filter from the Bouguer anomaly (Block et al., 2009). This gravity regional-

(b)

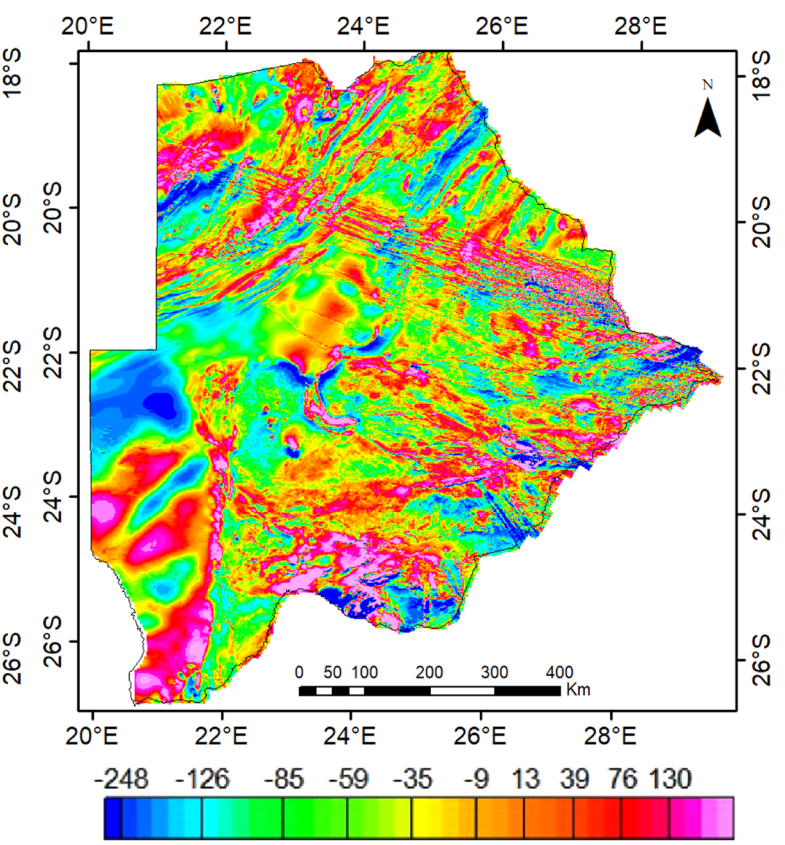

Figure 2. (a) The Bouguer anomaly map; and (b) the Total Magnetic Intensity (TMI) map. 
residual separation procedure (see: Blakely, 1995) made the residual gravity anomaly comparable to the magnetic anomalies of crustal sources (Leseane et al., 2015; Li et al., 2017). The filtered data represents an approximation of the crustal gravity signals, which was then used for apparent density calculation, as implemented in Geosoft's Oasis Montaj (2007). We set the average crustal density to $2,700 \mathrm{~kg} / \mathrm{m}^{3}$ and defined the layer model as the crustal layer from $200 \mathrm{~m}$, maximum thickness of Kalahari cover, for western Botswana and $0 \mathrm{~km}$ for exposed eastern part (Key and Ayres, 2000), to an estimated depth of $\sim 40 \mathrm{~km}$, the average crustal thickness of Botswana (Fadel et al., 2018) as parameters.

\section{Apparent Magnetic Susceptibility}

Apparent magnetic susceptibility mapping transforms the magnetic anomaly into magnetic susceptibility values (Letros et al., 1983). The process reduces signal overlaps from different bodies by removing the regional anomaly and enhancing lithological contacts of rocks with different susceptibilities. Firstly, we applied the reduction to the pole (RTP) filter to the aeromagnetic data to remove the effect of anomaly asymmetry caused by inclination of the magnetic field, so that anomalies are correctly positioned, above the causative bodies (Blakely, 1995). Due to the vastness of the study area, the RTP application was zoned to conform to the latitude and longitude of the region (Table 1) based on the International Geomagnetic Reference Field (Finlay et al., 2010). Then, the data was downward continued to $200 \mathrm{~m}$, the maximum thickness of Phanerozoic Kalahari sands (Key and Ayres, 2000), thereby calculating magnetic plane closer to the sources, reducing the spatial overlap between anomaly sources and making the source more distinguishable (Blakely, 1995). Curie point depth (CPD) in Botswana has an average value of $14 \mathrm{~km}$ based on the new world curie point depth map (Li et al., 2017), of higher depth values in the Nosop Basin and Northeastern Ghanzi-Chobe Zone. The calculated apparent magnetic susceptibility values in electromagnetic unit (e.m.u.) were then converted into SI unit by multiplying by a factor of 12.57 (Clark and Emerson, 1991). For clarification, we assume that the magnetizations in the study area are mainly due to induced magnetization. We do not consider the remnant magnetization effect in our processing.

\section{Apparent Physical Property Map}

The apparent physical properties map was produced through a fusion of the apparent density and apparent magnetic susceptibility maps using a color scheme approach (Everaerts, 1990; Yawsangratt, 2002; Chisenga, 2015). The average crustal density of $2,700 \mathrm{~kg} / \mathrm{m}^{3}$ was used as the cutoff point to separate high and low-density rocks. The apparent density map was assigned to a continuous color, cyan to yellow, representing low-density rocks and high-density rocks on each end, respectively. Zonation of apparent magnetic susceptibility used a subjective approach; rocks with higher apparent magnetic susceptibility than sedimentary rocks ( $\sim 0.018 \mathrm{SI})$ were classified as high susceptibility rocks, while rocks with lower magnetic susceptibility as sedimentary rocks were classified as low/non-magnetic susceptibility rocks. The apparent magnetic susceptibility map was assigned to a continuous color, from white to magenta, representing the non-magnetic rocks and the high magnetic rocks on each end, respectively. Then, we zoned the apparent physical property map based on the combined apparent densities and magnetic susceptibilities into four end-members. Colors were assigned to each end member as follows; (1) high-magnetic, high-density (HM-HD) represented by red, (2) high-magnetic, low-density (HM-LD) represented by blue, (3) low/non-magnetic, high density (LM-HD) represented by yellow, and (4) low/non-magnetic, low-density (LM-LD) represented by cyan. This was done to enable the joint spatial interpretation of the apparent physical property information.

\section{Results}

\section{Aeromagnetic Map}

In this section, we provided the steps on how we created a sketch map for the terranes that show high magnetic content ( $>120 \mathrm{nT}$ ), as shown in Fig 3, based on the aeromagnetic map, as shown in Fig. 4. Aeromagnetic map shows a crustal magnetization pattern in different locations and terranes (Fig. 4). The grayscale aeromagnetic map exhibits different magnetic zones and patterns in the data (Fig. 4a). In the south-

Table 1. Parameters for the apparent susceptibility calculation for each of the region

\begin{tabular}{ccccccc}
\hline \hline No & Region & $\mathrm{X}^{(*)}$ & $\mathrm{Y}^{(*)}$ & Inclination $^{(*)}$ & Declination $^{(*)}$ & Total magnetic intensity $^{(+)}$ \\
\hline 1 & Nosop basin & 20.96 & -24.04 & -64.11 & -14.2 & 28327.38 \\
2 & Kheis-Tshane 1 & 21.6 & -25.5 & -64.7 & -15.8 & 28029.56 \\
3 & Kheis-Tshane 1 & 21.9 & -25 & -63.88 & -14.12 & 28592.68 \\
4 & Okwa Block & 21.9 & -25.6 & -63.14 & -12.8 & 28941.16 \\
5 & Tsengeng Complex & 23 & -23.37 & -63.2 & -13.33 & 28769.11 \\
6 & Molopo Farm Complex & 24 & -25 & -63.9 & -15.3 & 28402.65 \\
7 & Xade Complex & 23.3 & -22.7 & -62.8 & -12.67 & 29012.59 \\
8 & Northwestern Botswana & 21.5 & -19.3 & -60.37 & -9.46 & 29948.41 \\
9 & Ghanzi-Chobe 1 & 21.81 & -28.8 & -65.59 & -19.6 & 27301.35 \\
10 & Ghanzi-Chobe 2 & 23 & -19.8 & -60.52 & -9.72 & 29833.76 \\
11 & Ghanzi-Chobe 3 & 23.8 & 18.7 & -59.24 & -8.65 & 30156.43 \\
12 & Ghanzi-Chobe 4 & 25 & -18.5 & -58.72 & -8.4 & \\
\hline
\end{tabular}

*Values are in degrees.

+ Values are in $\mathrm{nT}$. 


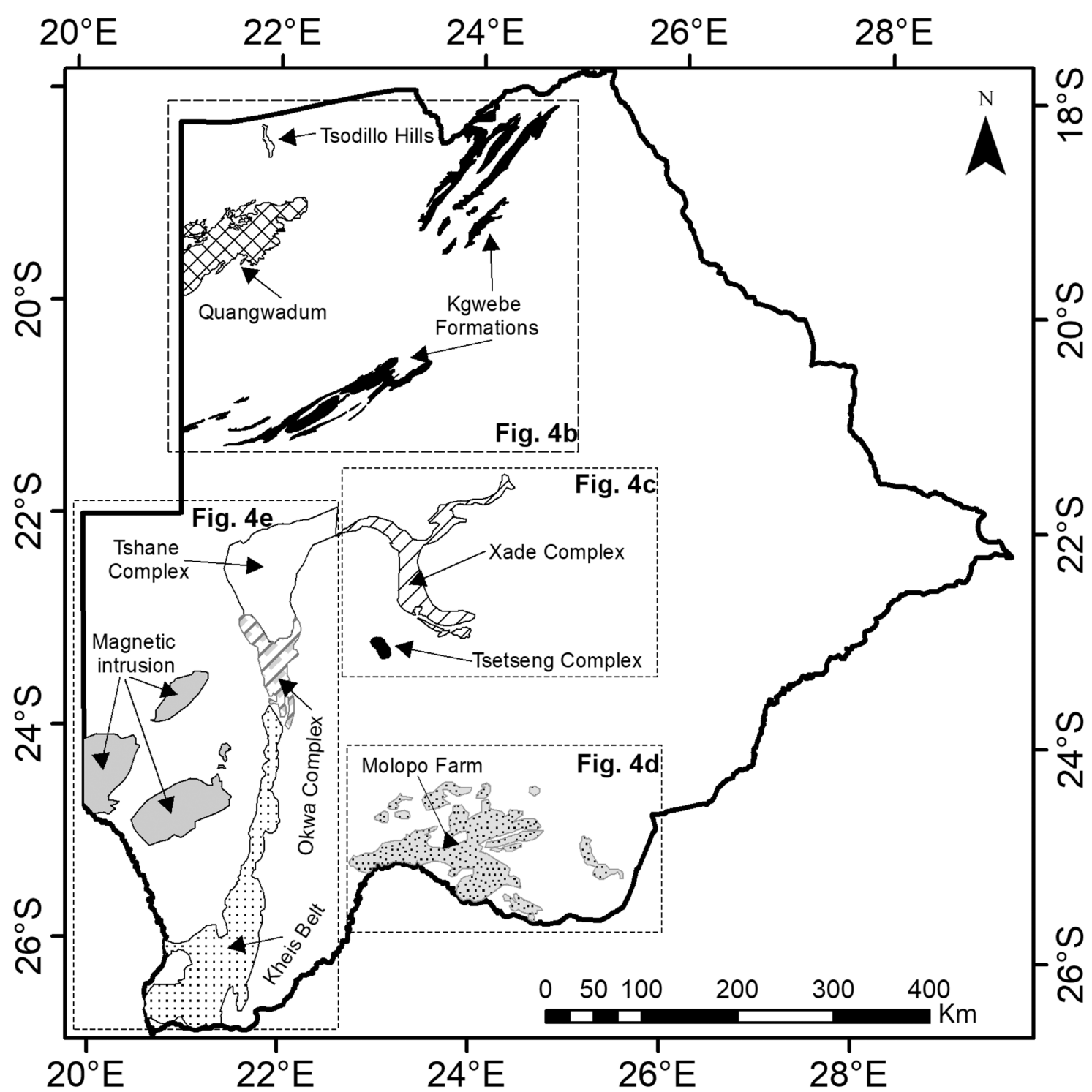

Figure 3. The sketch map for the magnetic bodies in Botswana identified from aeromagnetic data, as shown in Figs. 3 (b, c, d and e).

ern part, it is relatively difficult to differentiate the zones than in the northern part. Some of the areas that are identified are the dyke swarms, the Magondi Belt, the Kgwebe Formation and the Passarge Basin. Fig. 4b shows the large positive anomalies in the Quangwadum Complex, the Kgwebe Formation and the dyke swarms. Other occurrences of high magnetic bodies are located on the northeast side of Fig. 4b. Yawsangratt (2002) described them as granitic intrusions in the Ghanzi-Chobe Zone. The dyke swarms cross-cut the Kgwebe Formation in the GhanziChobe Zone in the central part of the map in Fig. 4b. This makes separation of the Kgwebe Formations and the dyke swarms emplacement at the locations $20^{\circ} \mathrm{S}$ and $22.5^{\circ} \mathrm{E}$ difficult. Fig. $4 \mathrm{c}$ shows two of the high magnetic bodies that are located in central Botswana. These bodies correspond to the Tsetseng and Xade Complexes that are interpreted as gabbroic intrusion and possible carbonatite, respectively (Reeves and Hutchins, 1982). Fig. 4d shows the Molopo Farm ultramafic complex, which has a large positive anomaly located in southern Botswana (Gould et al., 1987; Walker et al., 2010). The map also indicates some magnetic low within this complex (Fig. 4d). Finally, Fig. 4e shows the north-south trending high magnetic body that originates from Cape
Province in South Africa into central Botswana. It forms a magnetic high on the western edge of the Kaapvaal Craton. They correspond to the Kheis Belt, the Tshane Complex and the Okwa Block (Reeves and Hutchins, 1982). Within the Okwa Block, we identified a number of clustered high magnetic intrusions belonging to the Okwa inlier (Fig. 4e). On the western side of the map in Fig. 4e, there are three high magnetic intrusions/bodies that previously have not been mapped and are identified as part of basement structure in this study. The identified magnetic features form part of the tectonic terranes in Botswana, as shown on the sketch map in Fig. 3.

\section{Apparent Physical Properties Map}

The apparent physical properties map is based on apparent density map and apparent magnetic susceptibility map, as shown in Figs. 5a and $5 \mathrm{~b}$, respectively. The values were compared to measured densities (Hunt et al., 1995) and magnetic susceptibilities (Clark and Emerson, 1991). We associated physical significance to the calculated values by assigning their values to corresponding rock types found in Botswana 
(a)

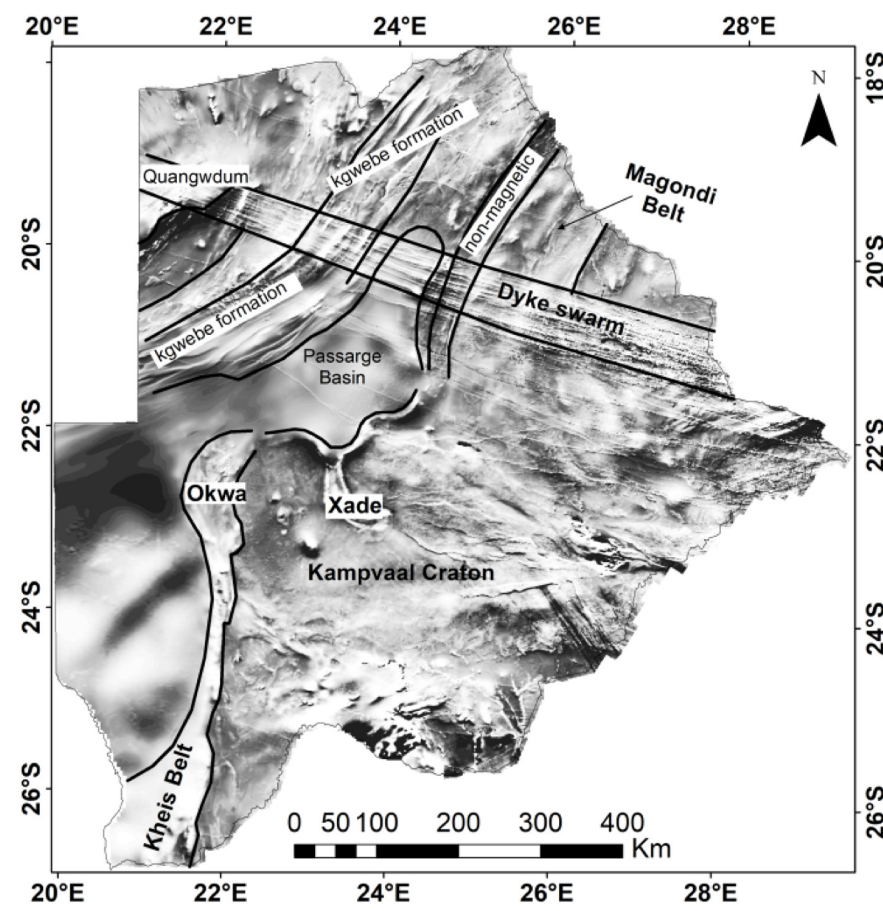

(c)

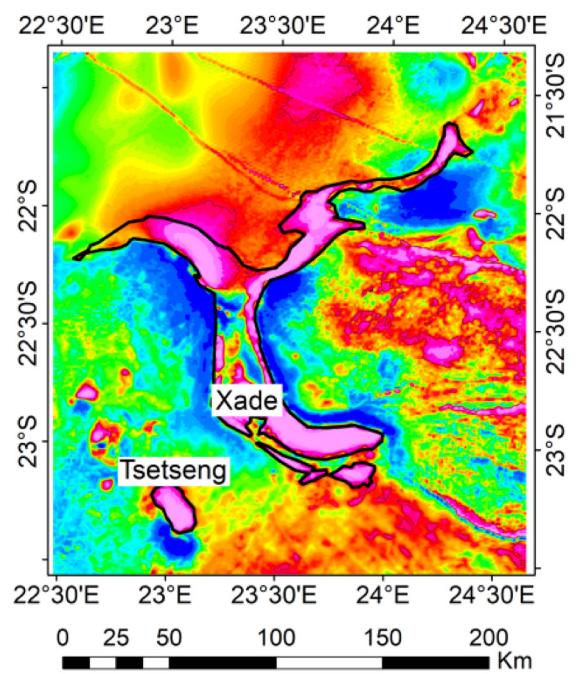

(b)

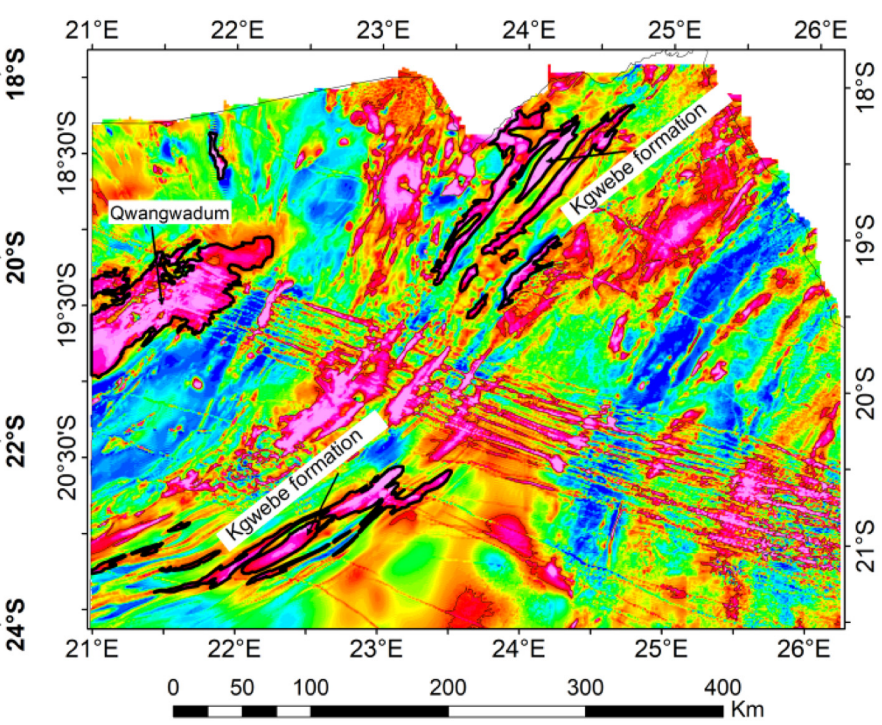

(e)

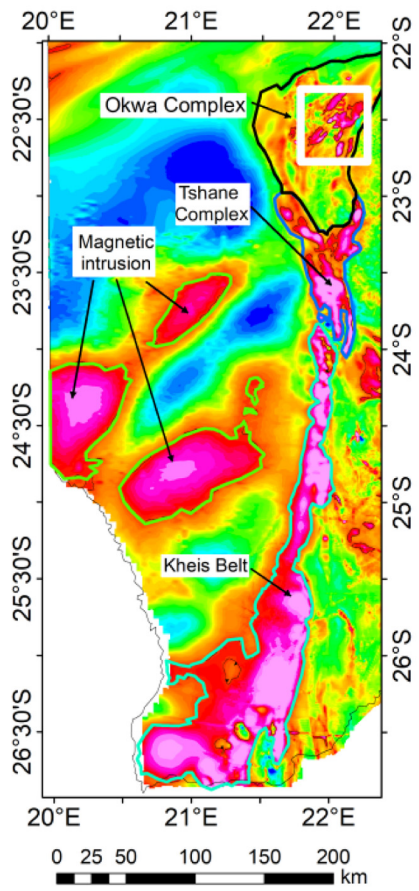

Figure 4. (a) Gray scale image of TMI that highlights the pattern in the magnetic data due to terrane similarities; and (b)-(e) highlighted high magnetic bodies in Botswana.

(Table 2). Based on the apparent physical properties map, as shown in Fig. 6, we identified regions with unique apparent physical properties, interpreted based on previous known information from other studies.

\section{Geotectonic Interpretation}

In this section, we significantly update the existing Precambrian basement tectonic map based on aeromagnetic information and its derived sketch map (Figs. 3 and 4) and the apparent physical properties map of Botswana (Fig. 6).

\section{Northwestern Botswana}

The northwestern Botswana refers to all tectonic terranes northwest of the Ghanzi-Chobe Zone. This region has three distinct apparent physical properties signature of LM-HD (yellow), LD-LM (cyan) and LD-HM (blue), suggesting a relatively uniform lithology over a large area, which has not undergone an extensive or a similar thermaltectono-metamorphic processes (Fig. 6).

In this region, a distinct feature is the high density and low magnetic belt, previously and partly mapped as rocks associated with granite gneiss and, to some extent, with amphibolite, locally called Roibok Complex (Key and Ayres, 2000; Singletary et al., 2003). The Precam- 
(a)

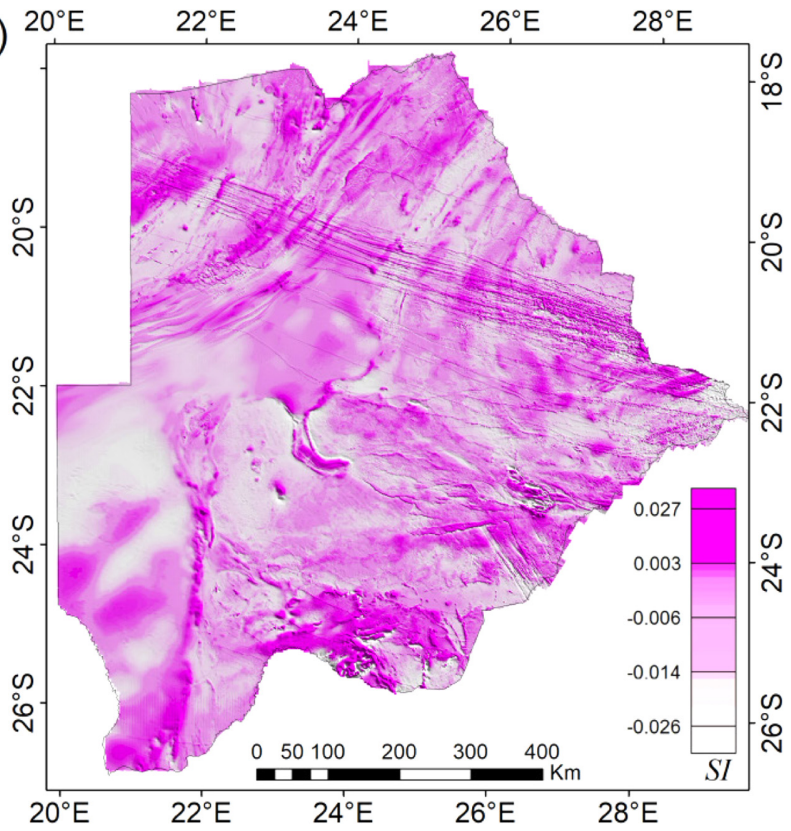

(b)

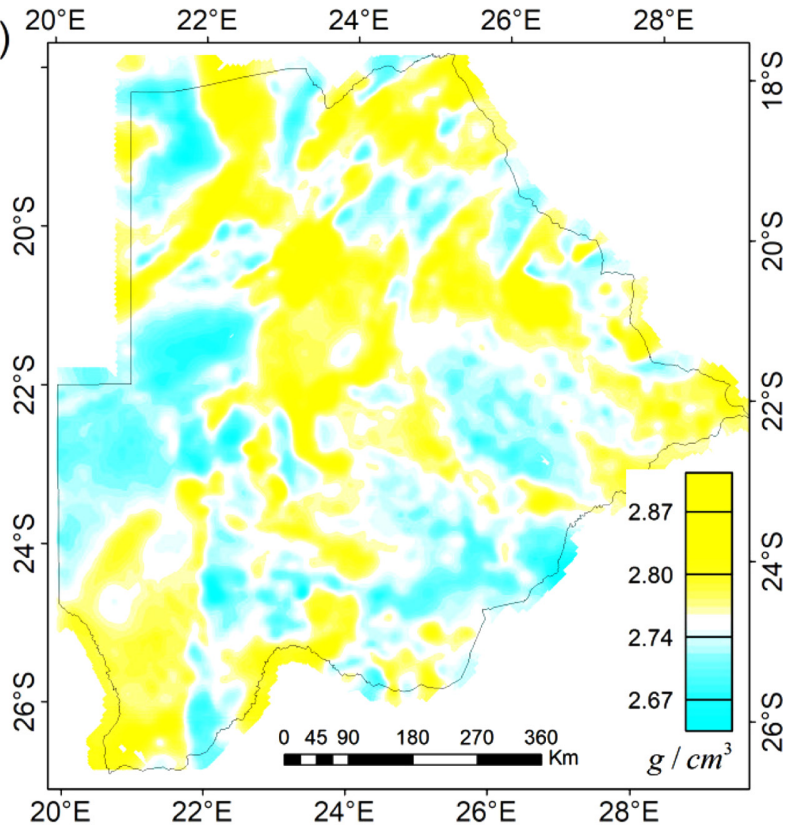

Figure 5. (a) Apparent magnetic susceptibility map. The calculation produced negative values, which represents non-magnetic rocks; (b) Apparent density map.

Table 2. Classification of rocks in Botswana based on geophysical information extracted from Fig. 5a and Fig. 5b, geological information obtained from Key and Ayres (2000), magnetic susceptibilities information obtained from Clark and Emerson (1991) and densities information obtained from Hunt et al. (1995). The second part of the table shows the classification of the physical map based on the information extracted from Fig. 6 in relation to rocks found in Botswana; based on combination of their densities and susceptibilities as shown in first part of the Table

\begin{tabular}{|c|c|c|c|c|c|c|c|c|c|}
\hline \multicolumn{2}{|c|}{$\begin{array}{l}\text { Mag Susceptibility } \\
\text { Classification }\end{array}$} & Range (SI) & \multicolumn{2}{|c|}{ Rock types } & Values (SI) & $\begin{array}{c}\text { Density } \\
\text { Classification }\end{array}$ & $\begin{array}{l}\text { Range } \\
\left(\mathrm{kg} / \mathrm{m}^{3}\right)\end{array}$ & Rock types & $\begin{array}{l}\text { Values } \\
\left(\mathrm{kg} / \mathrm{m}^{3}\right)\end{array}$ \\
\hline \multicolumn{2}{|c|}{$\begin{array}{l}\text { High magnetic } \\
\text { susceptibility }\end{array}$} & $\begin{array}{l}0.025 \text { and } \\
\text { above }\end{array}$ & \multicolumn{2}{|c|}{$\begin{array}{c}\text { Gabbro } \\
\text { Ultra-mafic rocks } \\
\text { Basic rocks } \\
\text { Gneissetic granitoid/migmatite/ } \\
\text { Granite gneiss } \\
\text { Granite } \\
\text { Dolerite }\end{array}$} & $\begin{array}{l}0.025 \\
0.05 \\
0.062\end{array}$ & low density & $2520-2670$ & $\begin{array}{c}\text { Syenite } \\
\text { Acidic igneous rocks } \\
\text { Granite } \\
\text { Sedimentary rocks }\end{array}$ & $\begin{array}{c}2500 \\
2610 \\
2640 \\
2300-2700\end{array}$ \\
\hline \multicolumn{2}{|c|}{$\begin{array}{l}\text { Low magnetic } \\
\text { susceptibility }\end{array}$} & . & \multicolumn{2}{|c|}{$\begin{array}{c}\text { Sedimentary rocks } \\
\text { Amphibolites }\end{array}$} & $\begin{array}{c}0.018 \\
0.0075\end{array}$ & high density & $2670-2900$ & $\begin{array}{l}\text { Granitic gneiss } \\
\text { Gneissetic granitoid } \\
\text { Dolerite } \\
\text { Amphibolite } \\
\text { Migmatite }\end{array}$ & $\begin{array}{l}2670 \\
2670 \\
2890 \\
2960 \\
2800\end{array}$ \\
\hline Color & Physical & neaning Densit & ity value $\left(\mathrm{kg} / \mathrm{m}^{3}\right)$ & Magnetic value & e (SI) & & & Rocks & \\
\hline $\begin{array}{c}\text { Blue } \\
\text { Red } \\
\text { Cyan Yellow }\end{array}$ & $\begin{array}{l}\text { LD- } \\
\text { HD- } \\
\text { LD- } \\
\text { HD- }\end{array}$ & & $\begin{array}{l}2520-2670 \\
2680-2900 \\
2520-2670 \\
2680-2900\end{array}$ & $\begin{array}{c}\text { Above } 0.025 \\
\text { Above } 0.025 \\
0-0.024 \\
0-0.024\end{array}$ & & $\begin{array}{r}\text { yenite, Granites } \\
\text { Ultram } \\
\text { Gabbro Sedim }\end{array}$ & $\begin{array}{l}\text { s, granite gne } \\
\text { lafic rocks, B } \\
\text { lentary rocks }\end{array}$ & $\begin{array}{l}\text { eiss, gnessetic granitoi } \\
\text { 3asic rocks, Migmatite } \\
\text { s Granite gneiss, Ampl }\end{array}$ & $\begin{array}{l}\text { d Dolerite, } \\
\text { 'ibolites }\end{array}$ \\
\hline
\end{tabular}

brian geological map of Singletary et al. (2003) indicates that some parts of the basement is concealed by young strata (Fig. 1). This obscured basement is partly an extension of the Roibox Complex underneath the strata. The similarity and continuation of the apparent physical property are characteristic to the Roibok Complex.

Key and Ayres (2000) describe the metasedimentary rocks north of the Quangwadum Complex as belonging to the Tsidilo Hill Group and the Xaudum Group. These two groups are distinguished due to the presence of ironstone in the Xaudum group, which are missing in the Tsidilo Hill Group. Thus, we separated these two regions and remapped them based on the apparent physical properties map. To the north of the Roibok Complex, the Tsodilo hill Group is characterised by intrusions of high magnetic bodies, which are comparable to the Tsodilo
Group on the western part. The region in between these two terranes belongs to the Xaudum Group.

Both the aeromagnetic map (Fig. 4b) and the apparent physical properties map (Fig. 6) have shown the extent of the Quangwadum Complex underneath the concealed geology. The terrane shows an HM-LD signature with densities of less than $2,670 \mathrm{~kg} / \mathrm{m}^{3}$ and magnetic susceptibilities above 0.025 . It is relatively larger than the previously geologically mapped terrane. Key and Ayres (2000) discussed the presence of syenite, granite, granitic gneiss and gnessetic granitoid that confirms the correlation between apparent physical signature and geological information of the Quangwadum Complex.

The Kwando Complex is located east of the Roibok Complex. It is defined by a northeasterly striking magnetic outcrops of granite gneiss, 


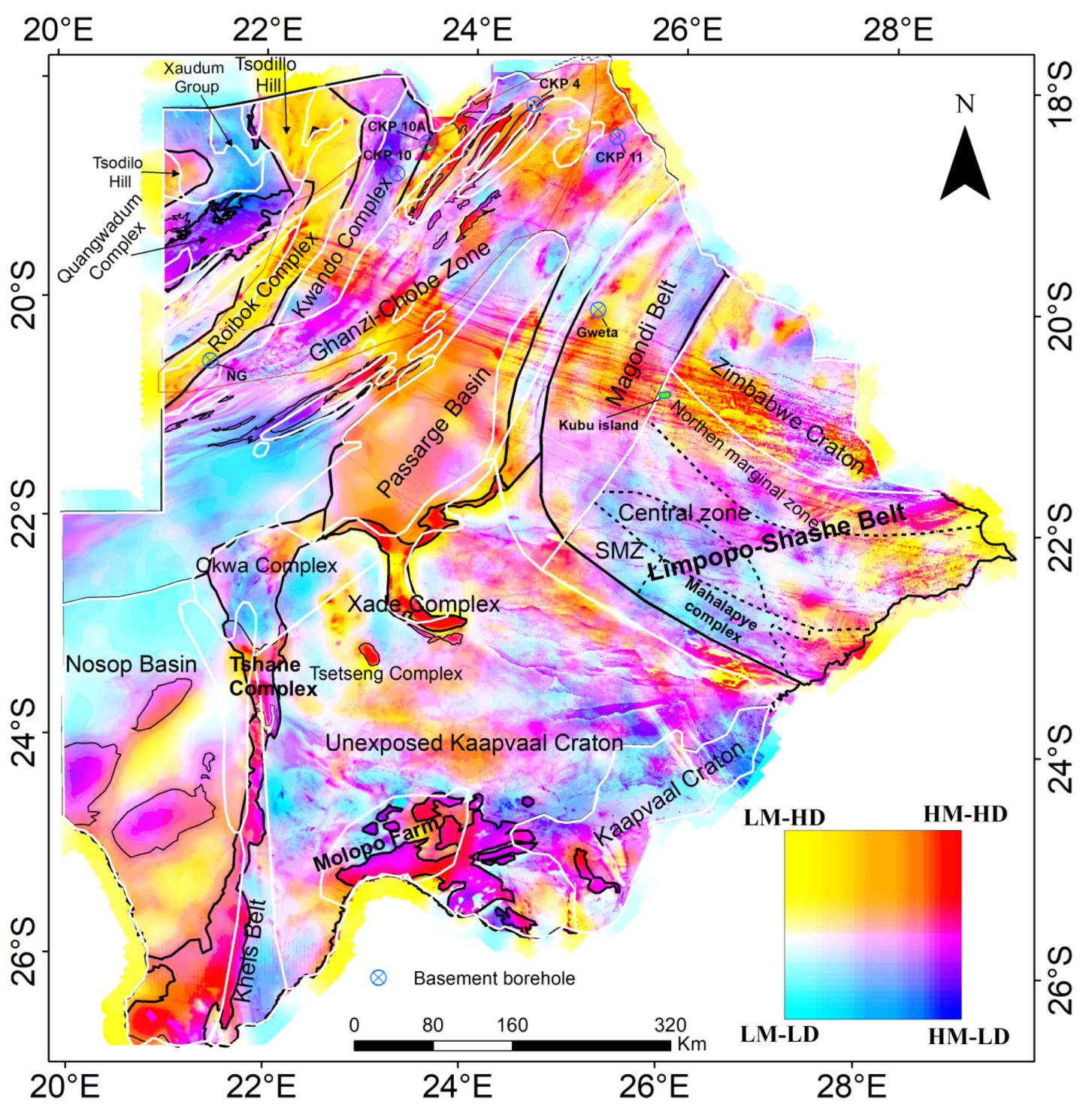

Figure 6. Apparent physical property map of Botswana based on the fusion of apparent density map, as shown in Fig. 5a and apparent magnetic susceptibility map as shown in Fig. 5b. Also shown are: (1) the Precambrian basement tectonic map of Botswana, which was presented in Fig. 1, as white polygons; (2) interpreted Precambrian basement tectonic map based on this study as black polygons, and (3) the basement borehole location as shown in Singletary et al. (2003).

granite, amphibole-gneiss, migmatite and meta dolerite (Carney et al., 1994). A borehole drilled in this region (CKP 10) intersected basement at $\sim 218 \mathrm{~m}$, which confirmed the presence of granite gneiss that contains thin, discontinuous, biotite-rich folia (Meixner and Peart, 1984). The northeastern boundary of the Kwando Complex cross-cut the Kgwebe Formation belonging to the Sinclair Group based on the high-magnetic signature. We redefined this boundary to the northwestern part of the high-magnetic and high-density Kgwebe Formation (Fig. 6). The new boundary also cross-cut the drillhole CKP 10A, whose core contained gabbroic to dioritic rocks dated to $\sim 1,107 \mathrm{Ma}$ (Meixner and Peart, 1984; Singletary et al., 2003). Singletary et al. (2003) interpreted this as part of the event that emplaced the basaltic and rhyolitic bodies of the Northwest Botswana Rift.

\section{Ghanzi-Chobe Zone}

The Ghanzi-Chobe Zone comprises the Ghanzi Group sediments and the Kgwebe Formation. The Okavango Rift System (Modisi, 2000) and the Okavango Dyke Swarms (Le Gall et al., 2005) are also located in or cut through the Ghanzi-Chobe Zone, respectively. The bimodal basaltic volcanism that formed the Kgwebe Formation occurred $\sim 1,106$ Ma during the initiation of the Northwest Botswana rift (Carney et al., 1994; Modie, 1996). The Giant Dyke Swarm of Botswana, which are highly magnetic due to its mafic composition of basalts, dolerites and minor gabbros, postdate the Kgwebe Formation occurring between $883 \mathrm{Ma}$ and $115 \mathrm{Ma}$ (Bertrand et al., 2002). Thus, this crosscutting relationship between the two magnetic bodies poses a great deal of a problem when interpreting the aeromagnetic data. In our interpretation, we included the mapped high-magnetic features with a northeasterly trend within the Ghanzi-Chobe Zone as belonging to the Kgwebe Formation (Fig. 4b). Nevertheless, we used the existing mapped features where the feature cross-cut the dyke swarms as aeromagnetic data could not differentiate the bodies (Fig. 6). 


\section{Sedimentary Basins}

The Passarge Basin is a Neoproterozoic sedimentary basin in central Botswana within the Ghanzi-Chobe Zone (Modie, 1996). It shows a HM-HD physical signature and a suppressed expected LM-LD sedimentary apparent physical property signature. Key and Ayres (2000) indicated the presence of magnetic meta-sediments in this region, while Corner et al. (2012) proposed that the high magnetic body in this region is the "Northern Lobe" of the Xade Complex extending into the Passarge Basin. Fadel et al. (2018) showed that the region has a possible mafic lower crust based on $\mathrm{Vp} / \mathrm{Vs}$ ratio. We suggest that the mafic region in the Passarge Basin is not an extension of the Xade Complex, but a separate mafic body with meta-sediments and mafic lower crust. Firstly, the relatively thin crust underneath the basin does not support the extension of the Xade Complex underneath the basin (Fadel et al., 2018). Secondly, the large part of the 'Northern Lobe' has different density rocks to that of the southern Xade Complex (Fig. 6). The extent of Passarge Basin is redefined based on the aeromagnetic and the apparent physical properties maps (Figs. 4a and 6). Aeromagnetic data shows a smooth texture in this region in which most of it conforms to the current boundary. Nevertheless, a different lithology appears on the western edge of the Passarge Basin that was redefined as the new boundary of the basin. Slightly magnetic signature are within the confinement of the boundary, which correspond to the geophysical studies (Mason, 1998; Key and Mapeo, 1999).

Key and Ayres (2000) describe the Nosop Basin as an accumulation of the Ghanzi Group sediments, which were overlain by the Nama Group sediments. The Nosop Basin has a thickness of $\sim 15 \mathrm{~km}$ (Key and Ayres, 2000). On average, this suggests basement thickness of $\sim 24 \mathrm{~km}$, based on $39 \mathrm{~km}$ average crustal thickness of the Nosop Basin after Fadel et al. (2018). In this region, there are three high-magnetic bodies with HM-HD signature on the apparent physical properties map (Figs. 4c and 6), underneath the $15 \mathrm{~km}$ thick sediments. This could indicate a presence of a possible thick mafic lower crust. The $\mathrm{V}_{\mathrm{p}} / \mathrm{V}_{\mathrm{s}}$ ratio suggests a felsic lower crust in this region, based on the $\mathrm{V}_{\mathrm{p}} / \mathrm{V}_{\mathrm{s}}$ map of Botswana by Fadel et al. (2018). However, we cannot be conclusive enough as Fadel et al. (2018) used two points, one in the northern Nosop and another one in the Kheis Belt, which are outside the high magnetic bodies, to extrapolate the lower felsic crust in this region. We have included these magnetic bodies as "mafic complexes of unknown age" in the interpreted Precambrian basement tectonic map of Botswana, as they show similar apparent physical signature to other mafic complexes. The origin of these mafic complexes would be further discussed in the discussion section.

\section{High Magnetic Bodies}

Mapping the magnetic bodies, started in the late 1970's (Hutchins and Reeves, 1980), with more additions to the initial understanding in following years (Gould et al., 1987; Le Gall et al., 2005; Corner et al., 2012; Ramotoroko et al., 2016). Some of the Proterozoic terranes that exhibit a magnetic signature in Botswana are the Kheis Belt, the Okwa Terrane, the Xade Complex and the Molopo Farms Complex (Key and Ayres, 2000). They exhibit average densities between 2,680 $\mathrm{kg} / \mathrm{m}^{3}$ and $2900 \mathrm{~kg} / \mathrm{m}^{3}$ (Fig. 5a) and magnetic susceptibilities above 0.025 (Fig. 5b). The Xade Complex, the Tsetseng Complex, the Tshane Complex, the Molopo Farm Intrusions and the Kheis Belt as they appear in the present Precambrian basement tectonic map (Key and Ayres, 2000; Singletary et al., 2003) are direct adaptation of first aeromagnetic mapping of Botswana (e.g., Hutchins and Reeves, 1980; Reeves and Hutchins, 1982). Then, the aeromagnetic data was of low resolution such that the spatial extents of these bodies were poorly constrained. Thus, we update the extent of these magnetic bodies as they appear on the aeromagnetic map (Figs. 3 and 4) and the apparent physical properties map (Fig. 6).

The Kheis Belt is the north-south trending highly magnetic body in the southwestern Botswana that defines the western edge of the Kaapvaal Craton. Hutchins and Reeves (1980) described it as a magnetic feature of folded sedimentary rocks with a low-density in the subsurface that extend from Cape Province in South Africa. The southern end of the Kheis Belt was previously mapped slightly east of the intrusion (Fig. 6). We suggest that the boundary should be slightly west of the current boundary in-line with the HM-HD signature on the apparent physical property map, as adopted from the aeromagnetic data (Fig. 4e).

The Tshane Complex is located north of the Kheis Belt and includes $\sim 200 \mathrm{~km}$ of unexposed Mesoproterozoic basic-ultrabasic bodies (Carney et al., 1994; Key and Ayres, 2000). The Tshane Complex is spatially bigger and slightly westward on the existing basement geology map (Fig. 6; Key and Ayres, 2000; Singletary et al., 2003) than on the apparent physical property map and aeromagnetic map (Figs. $4 \mathrm{~d}$ and 6). We base our interpretation on the spatial location and extent, including the shape of the Tshane Complex between the existing basement bodies and the structure as mapped on the aeromagnetic and apparent physical property information. We suggest that the Tshane Complex should be slightly smaller and to the east of the present mapped location, as indicated on Figs. 3 and 6.

The Okwa Block developed furthest north of the Tshane-Kheis Complex. Aldiss and Carney (1992) describe it as having an inlier magnetic feature belonging to the Kaapvaal Craton, within a mafic and felsic composition of the Okwa Complex. The Okwa inlier appears as a small mafic intrusion (white polygon in Fig. 4e) surrounded by the LM-LD area (Fig. 6). We define the region with a similar magnetic pattern as the extent of the Okwa Complex and the isolated magnetic bodies as the Okwa inlier (Fig. 6).

Two magnetic bodies are also visible within the central part of Botswana; the Xade Complex and the Tsetseng Complex. The Xade Complex is completely covered by the sedimentary rocks of the Kalahari Group but shows both HM-HD values (Fig. 6). Nevertheless, due to high resolution of aeromagnetic data in comparison with gravity data, we used the extent of the aeromagnetic data in this region (Fig. 4c) to redefine the boundary of the Xade Complex based on the interpreted basement geology map of Botswana. We also used the same approach to map a highly magnetic but smaller and almost circular Tsetseng Complex. The Molopo Farm Complex is highly magnetic ultrabasic intrusions in southern Botswana. Despite being an ultrabasic complex, some parts of the Molopo Farms have an HM-LD response and signature. The Molopo Farm Complex was actually delineated based on limited aeromagnetic data, which did not cover the entire intrusion (Hutchins and Reeves, 1980). The region is also known to be in proximity with some remnant of banded iron formations (Smith and Beukes, 2016) and is associated to the layered mafic complex of the Kaapvaal Craton and the Bushveld Complex (Viljoen, 2016). Thus, we used the current data to reinterpret the full extent of these features. 


\section{Eastern Botswana}

In this paper, Eastern Botswana is defined as the collection of tectonic terranes located between the eastern part of the Kaapvaal Craton and the southeastern part of the Ghanzi-Chobe Zone. This definition places the Magondi Belt, the Limpopo-Shashe Belt and the Zimbabwe Craton as the terranes within Eastern Botswana.

Key and Ayres (2000) described the Magondi Belt as a northeasttrending magnetic terrane of northeast Botswana that connects to the exposed southwestward trending Magondi Belt segment in Zimbabwe. The lithological similarities of the unexposed Magondi Belt beneath the Karroo strata in Botswana was confirmed by correlating the lithologies intersected at a drillhole in the Gweta area with the exposed Magondi Belt in the Dett area in Zimbabwe (Carney and Dowsett, 1991). Aeromagnetic information allowed us to highlight this northeast-trending structure in east Botswana with clear boundaries to the north and south (Fig. 4a). This is also confirmed on the apparent physical properties map where major density bodies are aligned with the defined boundaries forming an abrupt transition from HM-HD to HM-LD region (Fig. 6). We readjusted the boundary of the Magondi Belt along this features but considering the occurrence of Kubu Island Granite, as shown in Fig. 6. The Kubu Island Granite in the Sua Pan area is geologically defined as a granitic intrusion in the Archean crust that forms the southeastern boundary of the Magondi Belt with the Zimbabwe Craton (Key and Ayres, 2000; Majaule et al., 2001). The Magondi Belt makes a boundary with a northeastern trending narrow non-magnetic feature, approximately $370 \mathrm{~km}$ long and $25 \mathrm{~km}$ wide in the north. Perhaps, the feature represent the opening of the major Kalahari Suture, and it spatially correlate with the feature mapped by Hutchins and Reeves (1980).

The boundary between the Magondi Belt and the Limpopo-Shashe Belt is not clearly seen on the geophysical data. Thus we adopted the boundaries defined by Ranganai et al. (2002). They used gravity data and existing geological information to define the boundary between the Limpopo-Shashe Belt and the Zimbabwe Craton as the Shashe thrust zone (Ranganai et al., 2002). Then, the three division of the LimpopoShashe Belt (SMZ, CZ and NMZ) were defined based on the lithological and structural similarities. The Shashe Shear Zone forms a boundary with the Zimbabwe Craton, and the Dinokwe Thrust forms a boundary with the Kaapvaal Craton, while the Lechana Fault and Mahalapye Shear Zone separate the $\mathrm{CZ}$ from SMZ and NMZ. This readjustment is in line with the current interpretation on the apparent physical property map, despite that the present boundary between the Kaapvaal Craton and the Limpopo-Shashe Belt was slightly westward of the newly interpreted boundary.

\section{Interpreted Precambrian Basement Tectonic Map of Botswana}

The above interpretation of the aeromagnetic map (Figs. 3 and 4) and apparent physical properties map (Fig. 6) has led to the production of an updated Precambrian tectonic map of Botswana (Fig. 7). The newly interpreted map satisfied both geophysical and geological constraints and show tectonic boundaries of these geological terranes.

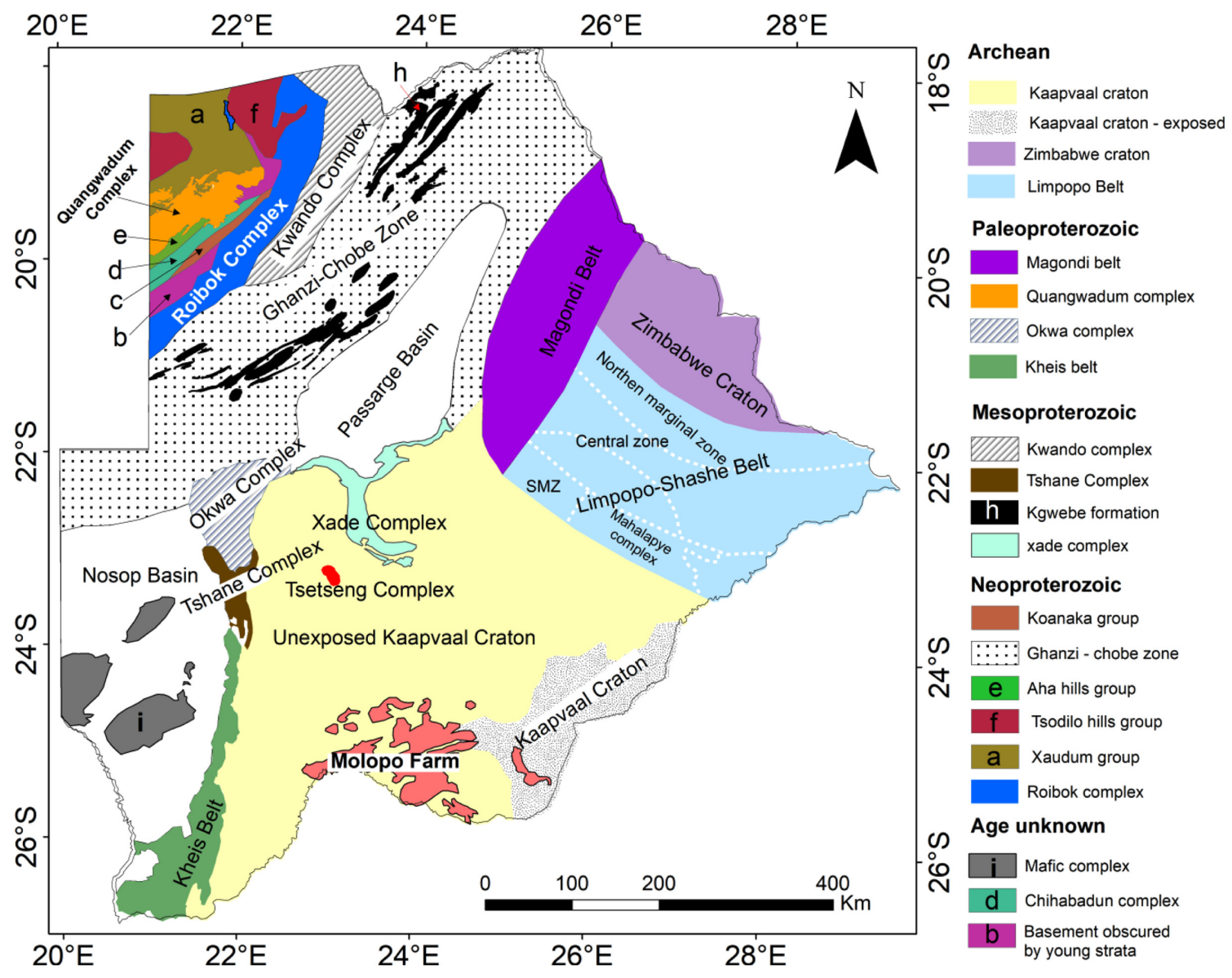

Figure 7. The interpreted subsurface Precambrian basement tectonic map of Botswana with updated tectonic terrane boundaries. 


\section{Discussion}

The updated tectonic terrane boundaries of the Precambrian basement structure (Fig. 7) exhibit the Proterozoic and Archean crust amalgamation, which show the tectonic and geological configuration beneath the thick Kalahari sedimentary cover. Northwestern Botswana is geologically identified as a Proterozoic terrane based on a few mapped outcrops (Key and Ayres, 2000) that belong to the Damara orogenic belt (Begg et al. 2009). However, recent studies using seismic data (Fadel et al., 2018) and magnetotelluric data (Khoza et al., 2013) have indicated that the region is a possible extension of an Archean Congo Craton into northwestern Botswana. This suggests that the region is a possible over-thrust collisional zone in which the Damara Belt lies on top of the Congo Craton. Furthermore, the geophysical properties of northwestern Botswana are similar to those of the southern part of the Kaapvaal Craton in Botswana, with patches of HM-HD rocks. As discussed, the preservation of physical properties in northwestern Botswana can complement the seismic, gravity and magnetotelluric studies to indicate the stability of this region, thus could suggest a cratonic signature. This is just a proposal as more geophysical investigations, especially seismics, needs to be done to verify this assertion and the lithospheric thickness in this area.

Another possible cratonic region is located in the northern part of the Nosop Basin. Fadel et al. (2018) and Fadel et al. (2020) argued for the presence of the Maltahohe micro-craton in the northern end of the Nosop Basin, based on their crustal thickness and $\mathrm{V}_{\mathrm{p}} / \mathrm{V}_{\mathrm{s}}$ ratio distribution and the shear wave velocities of the region, respectively. The buried craton is likely south of the suggested area, based on the similar physical signatures of the area to the proposed Congo Craton and the Kaapvaal Craton. The three mafic intrusions within the suggested region of the buried Maltahohe micro-craton could indicate intrusive events similar to the Bushveld intrusive event $\sim 2.05$ in the Kaapvaal craton However, we cannot be conclusive based on the data from this study as a denser network of seismic stations is required to determine the depth extension of these mafic intrusion, the lithospheric thickness of the keel and its seismic velocity, rather than just based on the argument of an apparent physical properties results and crustal thickness values. Moreover, the 3D shear wave velocity model of Fadel et al., (2020) had a coarse resolution of 1 degree that cannot provide a detailed image of the crustal structure of the region. Therefore, we propose seismological investigations to be conducted around the area that shows a relatively high magnetic signature. Since around the world, in all continents, most cratons present low density signature due to the nature of lithology associated with cratons.

\section{Conclusion}

In this paper, we have shown that the relationship between basement structure and apparent physical properties of rocks in Botswana can be investigated using gravity and magnetic properties. This has enabled us to define the configuration and extent of the geological units and tectonic terranes beneath the thick Kalahari sedimentary cover in Botswana. Thus, integrating seismological information, geologic structure and apparent physical properties of rocks, important conclusions could be reached regarding the crustal processes. By combining the apparent magnetic susceptibility and apparent density maps into an apparent physical properties map and its relation to the known geological structure, we have interpreted the geophysical information and produced an interpreted Precambrian basement tectonic map of Botswana.

\section{Acknowledgement}

We thank the Botswana Geoscience Institute (BGI), formerly the Geological Survey of Botswana, for providing the gravity and aeromagnetic data. This research was supported by a grant provided by Netherlands Organization for Scientific Research (NWO), grant number ALW-GO-AO/11-30, National Scientific Foundation of China (Grant No. U1831132 and 41374024) and Innovation Group of Natural Fund of Hubei province (Grant No. 2018CFA087).

\section{Reference}

Aldiss, D.T., 1991, The Motloutse Complex and the Zimbabwe Craton/ Limpopo Belt Transition in Botswana. Precambrian Research, v. 50, pp. 89-109.

Aldiss, D.T., and Carney, J.N., 1992, The geology and regional correlation of the Proterozoic Okwa Inlier, western Botswana. Precambrian Research, v. 56, pp. 255-274. doi:org/10.1016/0301-9268(92)90104-V

Begg, G.C., Griffin, W.L., Natapov, L.M., O'Reilly, S.Y., Grand, S.P., O'Neill, C.J., Hronsky, J.M.A., Djomani, Y.P., Swain, C.J., Deen, T., and Bowden, P., 2009, The lithospheric architecture of Africa: Seismic tomography, mantle petrology, and tectonic evolution. Geosphere, v. 5, pp. 23-50. doi:org/10.1130/GES00179.1

Bertrand, H., Gall, B. Le, Tshoso, G., Jourdan, F., Fe, G., Tiercelin, J.J., Kampunzu, B., Modisi, M.P., Dyment, J., and Maia, M., 2002, Ar / 39 Ar geochronology and structural data from the giant Okavango and related ma $\varnothing \mathrm{c}$ dyke swarms, Karoo igneous province, northern Botswana. Earth Planetary Science Letters, v. 202, pp. 595-606.

Blakely, R., 1995, Potential field if magnetic and gravity applications. Cambridge university press, Cambridge, UK.

Block, A.E., Bell, R.E., and Studinger, M., 2009, Antarctic crustal thickness from satellite gravity: Implications for the Transantarctic and Gamburtsev Subglacial Mountains. Earth Planetary Science Letters, v. 288, pp. 194-203. doi:org/10.1016/j.epsl.2009.09.022

Carney, J.N., Aldiss, D.T., and Lock, N., 1994, The geology of Botswana. Bull. Botswana 37.

Carney, J.N., and Dowsett, J.S., 1991, Lithological information from a borehole cored through cover and basement rocks near Gweta and its bearing on the distribution of major crustal boundaries in Botswana. Botswana Journal of earth Sciences, v. 1, pp. 1-13.

Chisenga, C., 2015, Understanding the earth structure underneath Botswana: The tectonic model and is relationship to the basement and crustal thickness. MSc thesis, ITC-University of Twente. The netherlands.

Clark, D.A., and Emerson, D.W., 1991, Notes on rock magnetization characteristics in applied geophysical studies. Exploration Geophysics, v. 22, pp. 547-555. doi:org/10.1071/EG991547

Corner, B., Verran, D.R., and Hilderbrand, P.R., 2012, Geophysical interpretation of the nature and extent of the Xade mafic comple, Botswana. South African Journal of Geology, v. 44, pp. 33-39. doi:org/10.2113/gssajg. 115.4 .

Coward, M.P., and Fairhead, J., 2002, Gravity and Structural evidence for the deep structure of the Limpopo Belt, southern Africa. Tectonophysics, v. 68, pp. 31-43. doi:org/10.1016/0040-1951(80)90007-4

Eglington, B.M., and Armstrong, R.A., 2004, The Kaapvaal craton and adja- 
cent orogens, southern Africa: A geochronological database and overview of the geological development of the craton. South african Journal of Geology, v. 107, pp. 13-32. doi:org/10.2113/107.1-2.13

Emry, E.L., Shen, Y., Nyblade, A., Flinders, A., and Bao, X., 2019, Upper Mantle Earth Structure in Africa From Full-Wave Ambient Noise Tomography. Geochemistry, Geophysics, Geosystems, v. 20, pp. 120147. doi:org/10.1029/2018GC007804

Evans, D.M., Hunt, J.P.P.M., and Simmonds, J.R., 2016, An overview of nickel mineralisation in Africa with emphasis on the Mesoproterozoic East African Nickel Belt ( EANB ). Episodes, v. 39, pp. 319-333. doi:org/ 10.18814/epiiugs/2016/v39i2/95780

Everaerts, M., 1990, The compilation and interpretation of geophysical data from the Mount Isa Area, N.W.Queensland, with the support of a geographical information system. MSc thesis, ITC-University of Twente. The netherlands.

Fadel, I., Paulssen, H., van der Meijde, M., Kwadiba, M.T, Ntibinyane, O., Nyblade, A., and Durrheim, R., 2018, Crustal and upper mantle shear wave velocity structure of Botswana: the April 3, 2017, central Botswana earthquake linked to the East African Rift System. Geophysical Research Letters, v. 47. doi:org/10.1029/2019GL085598.

Fadel, I., van der Meijde, M., and Paulssen, H., 2018, Crustal structure and dynamics of Botswana. Journal of Geophysical Research: Solid Earth, v. 123, pp. 10658-10671. doi:org/10.1029/2018JB016190

Finlay, C.C., Maus, S., Beggan, C.D., Bondar, T.N., Chambodut, A., Chernova, T.A., Chulliat, A., Golovkov, V.P., Hamilton, B., Hamoudi, M., Holme, R., Hulot, G., Kuang, W., Langlais, B., Lesur, V., Lowes, F.J., Macmillan, S., Mandea, M., Mclean, S., Manoj, C., Menvielle, M., Michaelis, I., Olsen, N., Rauberg, J., Rother, M., Sabaka, T.J., Tangborn, A., Th, E., Thomson, A.W.P., Wardinski, I., Wei, Z., and Zvereva, T.I., 2010, International Geomagnetic Reference Field: the eleventh generation. Geophysical Journal International, v. 183, pp. 1216-1230. doi:org/ 10.1111/j.1365-246X.2010.04804.x

Frost-killian, S., Master, S., Viljoen, R.P., and Wilson, M.G.C., 2016, The Great Mineral Fields of Africa Introduction. Episodes, v. 39, pp. 85-103. doi:org/10.18814/epiiugs/2016/v39i2/95770

Geosoft's Oasis Montaj, 2007, Geosoft mapping and application system, Inc.

Gould, D., Rathbone, P.A., and Kimbell, G.S., 1987, The geology of the Molopo Farms Complex, southern Botswana, Geological Survey of Botswana.

Gray, D.R., Foster, D., Meert, J., Goscombe, B., Armstrong, B., Trouw, R., and Passchier, C., 2008, A Damara orogen perspective on the assembly of south- western Gondwana. Geological Society of London, Special Publication, v. 294, pp. 257-278.

Gupta, V.K. and Grant, F.S., 1985, Mineral-exploration aspects of gravity and aeromagnetic surveys in the Sudbury-Cobalt area, Ontario., in: Hinze, W.J. (Ed.), The Utility of Regional Gravity and Magnetic Anomaly Maps. Society of Exploration Geophysicists, pp. 392-412.

Haddon, I.G., 2005, The Sub-Kalahari Geology and Tectonic Evolution of the Kalahari Basin, Southern Africa. PhD Thesis. University of Witswatesland.

Hartnady, C., Oubert, P., and Stowe, C., 1985, Proterozoic Crustal Evolution in Southwestern Africa. Episodes, v. 8, pp. 236-244. doi:org/10.18814/ epiiugs/1985/v8i4/003

Hunt, C.P., Moskowitz, B.M., and Banerjee, S.K., 1995, Magnetic properties of rocks and minerals, in: Ahrens, T.J. (Ed.), A Handbook of Physical Constants. American Geophysical Union, pp. 189-204. doi:org/10.1029/ RF003

Hutchins, D.G. and Reeves, C.V., 1980, Regional geophysical exploration of the Kalahari in Botswana. Tectonophysics, v. 69, pp. 201-220. doi:org/ 10.1016/0040-1951(80)90211-5

Kampunzu, A.B., 2000, Ion microprobe U-Pb ages on detrital zircon grains from the Ghanzi Group: implications for the identification of a Kibaranage crust in northwest Botswana. Journal of African Earth Sciences, v. 30, pp. 579-587.
Key, R., and Mapeo, R., 1999, The Mesoproterozoic history of Botswana and the relationship of the NW Botswana Rift to Rodinia A report on the second annual meeting of IGCP 418 - The Kibaran of. Episodes, v. 22, pp. 118-129.

Key, R.M., and Ayres, N., 2000, The 1998 edition of the National Geological Map of Botswana. Journal of African Earth Sciences, v. 30, pp. 427-451. doi:org/10.1016/S0899-5362(00)00030-0

Khoza, D., Jones, A.G., Muller, M.R., Evans, R.L., Webb, S.J., and Miensopust, M., 2013, Tectonic model of the Limpopo belt: Constraints from magnetotelluric data. Precambrian Research, v. 226, pp. 143-156. doi:org/10.1016/j.precamres.2012.11.016

Khoza, T.D., Jones, A.G., Muller, M.R., Evans, R.L., Miensopust, M.P., and Webb, S.J., 2013, Lithospheric structure of an Archean craton and adjacent mobile belt revealed from 2-D and 3-D inversion of magnetotelluric data: Example from southern Congo craton in northern Namibia. Journal of Geophysical Research, v. 118, pp. 4378-4397. doi:org/10.1002/ jgrb.50258

Kinnaird, J.A., Nex, P.A.M., and Milani, L., 2016, Tin in Africa. Episodes, v. 39, pp. 361-380. doi:org/10.18814/epiiugs/2016/v39i2/95783

Kröner, A., 1985, Pan African Crustal Evolution. Episodes, v. 3, pp. 3-8. doi.org/10.18814/epiiugs/1980/v3i2/001

Le Gall, B., Tshoso, G., Dyment, J., Basira Kampunzu, A., Jourdan, F., Féraud, G., Bertrand, H., Aubourg, C., and Vétel, W., 2005, The Okavango giant mafic dyke swarm (NE Botswana): Its structural significance within the Karoo Large Igneous Province. Journal of Structural Geology, v. 27, pp. 2234-2255. doi:org/10.1016/j.jsg.2005.07.004

Leseane, K., Atekwana, E. A., Mickus, K.L., Abdelsalam, M.G., and Shemang, E.M., 2015, Thermal perturbations beneath the incipient Okavango Rift Zone, northern Botswana. Journal of Geophysical Research: Solid Earth, v. 120, pp. 1210-1228. doi:org/10.1002/2014JB011029

Letros, S.W., Strangway, D.W., and Geissman, J., 1983, Apparent susceptibility mapping in the Kirkland Lake area, Ontario, Abitibi greenstone belt, Canada. Journal of Earth Sciences, v. 20, pp. 548-560.

Li, C., Lu, Y., and Wang, J., 2017, A global reference model of Curie- point depths based on EMAG2. Scientific Report, pp. 1-9. doi:org/10.1038/ srep45129

Majaule, T., Hanson, R.E., Key, R.M., Singletary, S.J., Martin, M.W., and Bowring, S.A., 2001, The Magondi Belt in northeast Botswana: Regional relations and new geochronological data from the Sua Pan area. Journal of African Earth Sciences, v. 32, pp. 257-267. doi:org/10.1016/S08995362(01)90006-5

Mapeo, R.B.M., Ramokate, L. V., Corfu, F., Davis, D.W., and Kampunzu, A.B., 2006, The Okwa basement complex, western Botswana: U-Pb zircon geochronology and implications for Eburnean processes in southern Africa. Journal of African Earth Sciences, v. 46, pp. 253-262. doi:org/ 10.1016/j.jafrearsci.2006.05.005

Mason, R., 1998, Tectonic setting of the Kalahari suture zone - Botswana, in: McMullan, S., Paya, B., Holmes, H. (Eds.), Abstracts, International Conference on the Role of a National Geological Survey in Sustainable Development. Geological Survey of Botswana, Gaborone, pp. 51-53.

Master, S., Bekker, A., and Hofmann, A., 2010, A review of the stratigraphy and geological setting of the Palaeoproterozoic Magondi Supergroup, Zimbabwe - Type locality for the Lomagundi carbon isotope excursion. Precambrian Research, v. 182, pp. 254-273. doi:org/10.1016/j.precamres.2010.08.013

McCourt, S., Van Reenen, D., Roering, C., Smit, A., 1995, Geological constraints on the Limpopo Orogeny, Geological Society of South Africa, Abstracts Centennial Geocongress. Johannesburg.

Meixner, H.M., and Peart, R.J., 1984, The Kalahari Drilling Project, Botswana Geological Survey.

Modie, B.N., 2000, Geology and mineralisation in the Meso- to Neoproterozoic Ghanzi-Chobe belt of northwest Botswana. Journal of African Earth Sciences, v. 30, pp. 467-474. doi:org/10.1016/S0899-5362(00)00032-4

Modie, B.N.J., 1996, Depositional environments of the Meso- to Neoproterozoic Ghanzi-Chobe belt, northwest Botswana. Journal of African 
Earth Sciences, v. 22, pp. 255-268. doi:org/10.1016/0899-5362 (96)00014-0

Modisi, M.P., 2000, Fault system at the southeastern boundary of the Okavango Rift, Botswana. Journal of African Earth Sciences, v. 30, pp. 569-578. doi:org/10.1016/S0899-5362(00)00039-7

Pedley, A., Neubert, J., and Klauw, S. van der, 2016, Potash deposits in Africa. Episodes, v. 39, pp. 447-457. doi:org/10.18814/epiiugs/2016/ v39i2/95787

Ramotoroko, C.D., Ranganai, R.T., and Nyabeze, P., 2016, Extension of the Archaean Madibe-Kraaipan granite-greenstone terrane in southeast Botswana: Constraints from gravity and magnetic data. Journal of African Earth Sciences, v. 123, pp. 39-56. doi:org/10.1016/j.jafrearsci. 2016.06.016

Ranganai, R.T., Kampunzu, A.B., Atekwana, E.A., Paya, B.K., King, J.G., Koosimile, D.I., and Stettler, E.H., 2002, Gravity evidence for a larger Limpopo Belt in southern Africa and geodynamic implications. Geophysical Journal International, v. 149. doi:org/10.1046/j.1365-246X. 2002.01703.x

Reeves, C.V. and Hutchins, D.G., 1982, A progress report on the geophysical exploration of the Kalahari in Botswana. Geoexploration, v. 20, pp. 209-224. doi:org/10.1016/0016-7142(82)90022-9

Roering, C., Reenen, D.D. Van, Smit, C.A., Jr, J.M.B., Beer, J.H. De, and Wit, M.J. De, 1992, Tectonic model for the evolution of the Limpopo Belt. Precambrian Research, v. 55, pp. 539-552. doi:org/10.1016/03019268(92)90044-O

Sarafian, E., Evans, R.L., Abdelsalam, M.G., Atekwana, E., Elsenbeck, J., Jones, A.G., and Chikambwe, E., 2018, Imaging Precambrian lithospheric structure in Zambia using electromagnetic methods. Gondwana Research, v. 54, pp. 38-49. doi:org/10.1016/j.gr.2017.09.007

Schaller, M., 1999, Exhumation of Limpopo Central Zone granulites and dextral continent-scale transcurrent movement at $2.0 \mathrm{Ga}$ along the Palala Shear Zone, Northern Province, South Africa. Precambrian Research, v. 96, pp. 263-288. doi:org/10.1016/S0301-9268(99)00015-7

Schaller, M., Steiner, O., Studer, I., Holzer, L., Herwegh, M., and Kramers, J.D., 1999, Exhumation of Limpopo Central Zone granulites and dextral continent-scale transcurrent movement at 2.0 Ga along the Palala Shear
Zone, Northern Province, South Africa. Precambrian Research, v. 96, pp. 263-288.

Schannor, M., Lana, C., and Fonseca, M.A., 2019, São Francisco-Congo Craton break-up delimited by U-Pb-Hf isotopes and trace-elements of zircon from metasediments of the Araçuaí Belt. Geoscience Frontiers, v. 10, pp. 611-628. doi:org/10.1016/j.gsf.2018.02.011

Singletary, S.J., Hanson, R.E., Martin, M.W., Crowley, J.L., Bowring, S.A., Key, R.M., Ramokate, L. V., Direng, B.B., and Krol, M.A., 2003, Geochronology of basement rocks in the Kalahari Desert, Botswana, and implications for regional Proterozoic tectonics. Precambrian Research, v. 121, pp. 47-71. doi:org/10.1016/S0301-9268(02)00201-2

Smith, A.J.B., and Beukes, N.J., 2016, Palaeoproterozoic banded iron formation-hosted high-grade hematite iron ore deposits of the Transvaal Supergroup, South Africa. Episodes, v. 39, pp. 269-284. doi:org/10.18814/ epiiugs/2016/v39i2/95778

Thomas, R.J., von Veh, M.W., and McCourt, S., 1993, The tectonic evolution of southern Africa: an overview. Journal of African Earth Sciences, v. 16, pp. 5-24. doi:org/10.1016/0899-5362(93)90159-N

Treloar, P.J., 1988, The geological evolution of the Magondi Mobile Belt, Zimbabwe. Precambrian Research, v. 38, pp. 55-73. doi:org/10.1016/ 0301-9268(88)90093-9

Tucker, R.F., Viljoen, R.P., and Viljoen, M.J., 2016, A Review of the Witwatersrand Basin - The World's Greatest Goldfield. Episodes, v. 39, pp. 105-133. doi:org/10.18814/epiiugs/2016/v39i2/95771

Viljoen, M., 2016, The Bushveld Complex Host to the World's Largest Platinum, Chromium and Vanadium Resources. Episodes, v. 39, pp. 239-268. doi:org/10.18814/epiiugs/2016/v39i2/95777

Walker, A.S.D., Key, R.M., Pouliquen, G., Gunn, G., Sharrock, J., McGeorge, I., Koketso, M., and Farr, J., 2010, Geophysical Modelling of the Molopo Farms Complex in Southern Botswana: Implications for its Emplacement within the $\sim 2$ Ga Large Igneous Provinces of Southern and Central Africa. South African Journal of Geology, v. 113, pp. 381-400.

Yawsangratt, S., 2002. A gravity study of northern Botswana : a new perspective and its implications for regional geology. MSc thesis, ITCUniversity of Twente. The netherlands. 


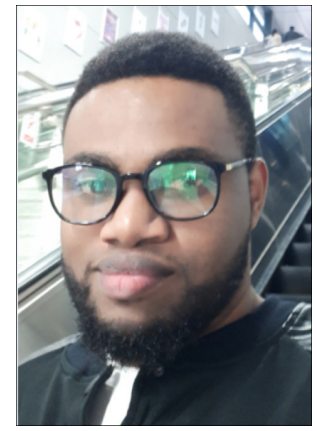

Chikondi Chisenga is a $\mathrm{PhD}$ candidate in Geodesy and Survey Engineering at Wuhan University in China. He is also a lecturer in Earth Sciences at the Malawi University of Science and Technology. He holds an MSc in Applied Earth Sciences from University of Twente, Netherlands and BSc in Earth Sciences from University of Malawi. His research interest is in the combining geophysics and geology to resolve and understand geodynamic processes and tectonic activities at continental/regional scale.

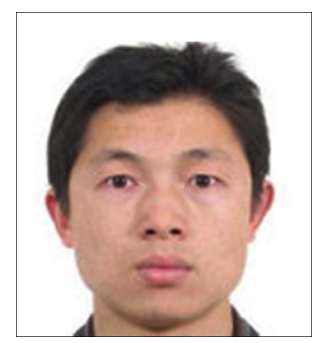

Yan Jianguo is a professor at the State Key Laboratory of Information Engineering in Mapping, Surveying and Remote Sensing (LIESMARS) of Wuhan University. His research interests include planetary spacecraft precise orbit determination, planetary gravity field recovery and its interior structure investigation. Currently, he is working on precise orbit determination of MEX and Rosetta, and precise Mars lander positioning with various tracking techniques. He employs dynamic orbit determination theory, and inversion theory.

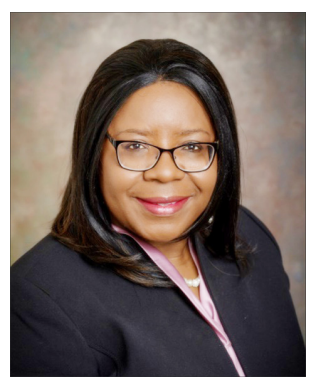

Mark van der Meijde is a professor on '3D geological modeling' in ITC's department of Earth Systems Analysis. He holds a PhD in Geophysics from the ETH Zurich, Switzerland and an MSc degree in earth sciences from Utrecht University (1998). His main research interest is the making the link between remotely sensed surface and subsurface information. Fields of application focus on geophysics, 3D geological modeling, integrating space and airborne (hyperspectral) remote sensing with seismology for geo-hazards and tectonics, and 3D environmental modeling, particularly focusing on detection of natural and manmade hydrocarbon leakages.

Estella A. Atekwana is a professor of geophysics and the dean of the College of Earth, Ocean, and Environment of the University of Delaware, USA. She holds a PhD in Geophysics from Dalhousie University, an MSc of Geology and a BSc of Geology, both from Howard University. She has taught at Oklahoma State University, Missouri University of Science \& Technology, Indiana University-Purdue University Indianapolis, and Western Michigan University. Her research interests are in Biogeophysics and Tectonics with focus on the geophysical investigations of incipient continental rift forming processes with particular attention to the East African Rift System Zone.

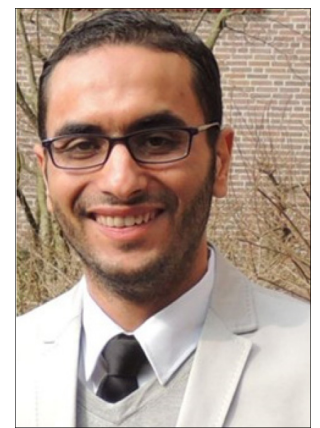

Islam Fadel is an assistant professor of geophysics in ITC's department of Earth Systems Analysis of the University of Twente. He holds a BSc in geophysics from Helwan University, Egypt, MSc in Geo-information Science and Earth Observations (ITC) with a specialization in Earth Resource Exploration and $\mathrm{PhD}$ in applied Earth Sciences (Geophysics) both from University of Twente, the Netherlands. He did post-doctoral studies in Geophysics at Delft Technical University, the Netherlands between 2017-2018. He previously worked as an instructor at Helwan University, Egypt, since September 2007 and as an instructor at Cairo University, Egypt in the academic year of 2010-2011. His PhD work was on the modeling the African lithosphere combining GOCE and seismology data. 